\title{
Growth Factor Expression in Aorta of Normotensive and Hypertensive Rats
}

\author{
Riccardo Sarzani, " Peter Brecher, ${ }^{\star *}$ and Aram V. Chobanian* \\ *Cardiovascular Institute and ${ }^{\ddagger}$ Department of Biochemistry, Boston University School of Medicine, Boston, Massachusetts 02118
}

\begin{abstract}
Hypertension causes biochemical and morphological changes in the vessel wall by unknown mechanisms. Locally produced substances may have a role in mediating these vascular changes. We have studied the expression of platelet-derived growth factor (PDGF) B chain and PDGF A chain, insulin-like growth factor (IGF)-I and IGF-II, endothelial cell growth factor (ECGF), basic fibroblast growth factor (bFGF), and transforming growth factor- $\beta$ (TGF- $\beta$ ) in aortic tissue from normotensive rats and rats made hypertensive by deoxycorticosterone (DOC)/salt treatment. Using Northern blotting, we found that genes for each of these growth factors were transcriptionally active in the aorta of both normotensive and hypertensive rats. TGF- $\beta$ aortic $m$ RNA levels increased up to threefold as a result of $\mathrm{DOC} / \mathrm{salt}$ hypertension. In contrast, no major changes in the expression of either PDGF chain, IGF-I or II, ECGF, or bFGF were detectable. The results indicate that at least seven genes coding for growth factors that were shown previously to influence growth and function of vascular cells in vitro, are expressed in rat aorta in vivo. These findings support the hypothesis that synthesis and release of growth factors in the arterial wall are involved in autocrine and/or paracrine regulatory mechanisms. In addition, the increased expression of TGF- $\beta$ in vivo may have a role in mediating the aortic changes induced by hypertension.
\end{abstract}

\section{Introduction}

Hypertension is a major risk factor for strokes, myocardial infarction, and peripheral vascular disease (1). Hemodynamic factors are important in the localization and initiation of atherosclerotic lesions $(2,3)$, and hypertension seems to accelerate atherogenesis in experimental animal models as well as in humans $(3,4)$. Even in species resistant to dyslipidemia and lipid deposition in the arterial wall, such as the rat, hypertension causes a large number of functional and morphological alterations in the vessel wall, including hypertrophy and increased turnover of endothelial cells $(3,5)$, hypertrophy, polyploidy, and intimal migration of medial smooth muscle cells $(\operatorname{SMC})^{1}(3,6)$, adhesion and subendothelial migration of

Address correspondence to Dr. Riccardo Sarzani, Boston University School of Medicine, 80 East Concord Street, Boston, MA 02118.

Received for publication 21 November 1988 and in revised form 13 January 1989.

1. Abbreviations used in this paper: aFGF, acidic fibroblast growth factor; bFGF, basic fibroblast growth factor; DOC, deoxycorticoste-

J. Clin. Invest.

(C) The American Society for Clinical Investigation, Inc. $0021-9738 / 89 / 04 / 1404 / 05 \$ 2.00$

Volume 83, April 1989, 1404-1408 blood mononuclear cells (5), and extracellular matrix accumulation (3).

The molecular mechanisms whereby increased intravascular pressure affects the vessel wall in vivo are unknown. However, studies using cultured cells have indicated that a number of different polypeptide growth factors can influence vascular cell function and proliferation. Several growth factors have been shown to be made in vitro by endothelial cells (7-9), smooth muscle cells (9-11), and blood mononuclear cells (7, $12,13)$. Multiple effects of different growth factors on these cell types led to suggestions that complex autocrine and paracrine control mechanisms exist in vivo in vascular tissue (7, 12). With the exception of recent studies showing the presence of mRNAs for platelet-derived growth factor (PDGF) A- and $B$ chains in adult rat aorta (10) and increased mRNA for PDGF B chain suggested to be present in human atherosclerotic plaques (14), there is a paucity of data on local production of growth factors by vascular tissue in vivo.

In the current study we have used seven cDNA probes coding for different growth factors, shown previously to influence the growth and function of cultured vascular cells, to study growth factor mRNA expression in normotensive and hypertensive rat aortas. The choice of studying several different growth factors was made since they are likely to be part of a complex cellular signaling language (12); therefore, the changes in cell function and growth that occur in vivo in experimental hypertension could be due to the pattern of regulatory peptides to which cells are exposed.

\section{Methods}

Experimental animal models. Male Wistar rats (Charles River Breeding Laboratories, Inc., Wilmington, MA) were uninephrectomized at $10 \mathrm{wk}$ of age and a pellet containing $100 \mathrm{mg}$ deoxycorticosterone acetate (DOC; Innovative Research of America, Toledo, $\mathrm{OH}$ ) was implanted subcutaneously $1 \mathrm{wk}$ after uninephrectomy. At the same time, animals were given $1 \% \mathrm{NaCl}$ as drinking water. Control treatments included uninephrectomy alone and uninephrectomy plus DOC implant but with low sodium diet pellets $(0.4 \% \mathrm{NaCl}$; Teklad Inc., Madison, WI) and tap drinking water. For each treatment at least three groups of rats were prepared. Systolic BP was measured as previously described by tail cuff plethysmography and a photoelectric cell detector (5). BP measurements were made $1 \mathrm{~d}$ before killing the animals, and those with $150 \mathrm{mmHg}$ (and above) of systolic pressure were considered hypertensive. Average systolic pressures for groups of six rats treated with $\mathrm{DOC} /$ salt for 7,14 , or $21 \mathrm{~d}$ were 128,162 , and $185 \mathrm{mmHg}$, respectively. Uninephrectomized control rats had BPs that varied from 111 to $143 \mathrm{mmHg}$ during the treatment period. Animals were killed by an overdose of pentobarbital after the designated treatment period.

rone acetate; ECGF, endothelial cell growth factor; IGF, insulin-like growth factor; PDGF, platelet-derived growth factor; SMC, vascular smooth muscle cells; TGF- $\beta$, transforming growth factor beta. 
Aortas were cleaned of periadventitial tissues, rinsed in cold physiological saline solution, and quickly frozen in liquid nitrogen. For some experiments aortas were opened longitudinally and the endothelium scraped with a scalpel blade, followed by rinsing in cold physiological saline solution. Microscopic evaluation of comparable aortas showed complete loss of endothelium except in areas around the orifices of branch vessels. A minimum of three animals was included in each group and the aortas were pooled for RNA extraction.

RNA extraction and analysis. Total RNA was extracted using minor modifications of the guanidinium-thiocyanate/cesium chloride centrifugation method (15). $20 \mu \mathrm{g}$ of total RNA of each sample was quantified by UV spectrophotometry and separated through $1 \%$ agarose/1 M formaldehyde gel electrophoresis. Northern blotting was performed by capillary transfer in 10X standard saline citrate (SSC) (1 $\times \mathrm{SSC}$ is $0.15 \mathrm{M} \mathrm{NaCl}, 0.015 \mathrm{M}$ sodium citrate, $\mathrm{pH}$ 7) to nylon membrane (Gene Screen Plus; DuPont-New England Nuclear, Wilmington, DE). The membranes were briefly rinsed in $2 \times$ SSC and nucleic acid crosslinking was performed by ultraviolet irradiation for 6 min on a transilluminator (312-nm wavelength). The blots were then baked at $80^{\circ} \mathrm{C}$ for $1 \mathrm{~h}$ in a vacuum and hybridization was performed using the following modifications of a published procedure (16). Prehybridization was carried out for $2 \mathrm{~h}$ at $65^{\circ} \mathrm{C}$ in a hybridization buffer containing $1 \%$ BSA, $5 \times$ SSPE $(1 \times$ SSPE is $0.15 \mathrm{M} \mathrm{NaCl}, 0.01 \mathrm{M}$ sodium phosphate, $0.001 \mathrm{M} \mathrm{Na}_{2} \mathrm{EDTA}, \mathrm{pH}$ 7.4) supplemented with $\mathrm{NaCl}$ to reach $0.9 \mathrm{M} \mathrm{NaCl}, 4 \%$ SDS, $10 \%$ dextran sulfate, $500 \mu \mathrm{g} / \mathrm{ml}$ heparin, and $200 \mu \mathrm{g} / \mathrm{ml}$ sonicated and denatured salmon sperm DNA. Hybridization was performed for $20 \mathrm{~h}$ at $65^{\circ} \mathrm{C}$ using $\mathrm{cDNA}$ probes labeled by the random hexamer priming procedure (17). After hybridization, membranes were washed three times for $20 \mathrm{~min}$ at $55^{\circ} \mathrm{C}$ with $1 \%$ SDS and $1 \times, 0.5 \times$, and $0.2 \times$ SSC, respectively. Blots were then exposed to preflashed $x$-ray films (Kodak X-Omat) between two intensifying screens (Cronex lightning plus; DuPont Instruments, Wilmington, DE) for $6 \mathrm{~h}-5 \mathrm{~d}$ at $-80^{\circ} \mathrm{C}$. Developed films were scanned by laser densitometry to quantitate the relative signal intensity of the bands obtained. The size in kilobases of the detected mRNAs was calculated on the basis of the $18 \mathrm{~S}$ and $28 \mathrm{~S}$ ribosomal RNA migration from the gel wells.

cDNA probes. To detect specific mRNAs for the growth factors studied, the following human cDNA probes were used: (a) 1-kb c-SIS (PDGF B chain) obtained from Amersham Corp., Arlington Heights, IL, (b) 1.3-kb PDGF A chain from C.-H. Heldin and C. Betsholtz (18), (c) 1.1-kb insulin-like growth factor (IGF)-I B obtained from P. Rotwein (19), (d) 0.17-kb IGF-II (part of the coding region of the E domain) from M. Jansen (20), (e) 2.2-kb endothelial cell growth factor (ECGF) from American Type Culture Collection, Rockville, MD (deposited by M. Jaye; Meloy Laboratories Inc., Springfield, VA) (21), $(f)$ 1.4-kb basic fibroblast growth factor (bFGF) obtained from J. A. Abraham and J. C. Fiddes (California Biotechnology, Inc., Mountain View, CA) and D. Gospodarowicz (22), and $(g) 1.0-k b$ transforming growth factor- $\beta$ (TGF- $\beta$ ) from R. Derynck (Genentech Inc., South San Francisco, CA) (23). To validate the differences in hybridization signal intensities, a 1.5-kb rat $\beta$-actin cDNA probe was used as a control (24). The highly conserved sequences for growth factors between species $(9$, 13) was one factor that allowed us to study growth factor gene expression in rat tissues using human cDNAs.

\section{Results}

The expression of TGF- $\beta$ in aortic tissue from control and hypertensive rats is shown in Fig. 1. TGF- $\beta$ mRNA was expressed in approximately equivalent amounts in aortic tissue both containing and lacking endothelial cells, suggesting the medial SMC as the major source. A consistent increase in expression of TGF- $\beta$ mRNA was observed in aortas from hypertensive rats after DOC/salt treatment. Fig. 1 shows data using RNA from three separate groups of rats treated for $3 \mathrm{wk}$,

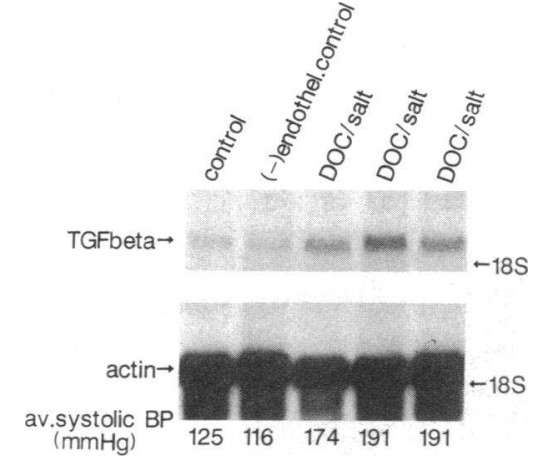

Figure 1. TGF- $\beta$ gene expression in aortic tissue. Northern blot hybridization analysis of rat aortic RNA from normotensive and hypertensive animals. 20 $\mu \mathrm{g}$ of total RNA from different groups of rat aortas was applied to each lane. $28 \mathrm{~S}$ and $18 \mathrm{~S}$ indicate the respective positions of ribosomal RNA. Average systolic

BP from each group of animals is shown at the bottom of each lane. (Top) TGF- $\beta$ gene expression. (-) endothel. control, RNA extracted from endothelium-scraped aortas of untreated rats. DOC/salt groups were all treated for $3 \mathrm{wk} .2 \mathrm{~d}$ exposure time. (Bottom) $\beta$-Actin gene expression. The same blot previously hybridized with human TGF- $\beta$ cDNA probe was rehybridized with a rat $\beta$-actin cDNA probe. $3 \mathrm{~h}$ exposure time.

each group consisting of a pool of at least three aortas. The increased expression observed after the third week of treatment was somewhat variable, with the level of TGF- $\beta$ transcripts increasing from 1.5- to 3-fold, as judged by laser densitometry of the preflashed films. DOC administered with a low salt diet for up to $3 \mathrm{wk}$ did not increase BP nor change TGF- $\beta$ expression (data not shown). Although a modest increase in mRNA appeared between 1 and 2 wk of DOC/salt administration, the most consistent change was after $3 \mathrm{wk}$ of DOC/salt administration, a time when BP was clearly elevated for at least $10 \mathrm{~d}$. In Fig. 1 (bottom) a $\beta$-actin cDNA probe was hybridized on the same blot to show the specificity of the change in gene expression and also as a control of the quality and quantity of the RNA present on the blot. The level of $\beta$-actin mRNA $(\sim 2.2 \mathrm{~kb})$ did not change as a result of DOC/salt treatment.

Fig. $2 A$ shows the presence of PDGF B chain transcripts in rat aorta. The size of the mRNA was $\sim 3.5 \mathrm{~kb}$ and the signal was readily detected. Uninephrectomized animals had expressions of aortic PDGF B similar to untreated control animals. The PDGF B chain mRNA levels in aortic tissue were similar to rats treated with $\mathrm{DOC} / \mathrm{salt}$ for 1,2 , or $3 \mathrm{wk}$, thereby encompassing both prehypertensive and hypertensive animals, and no differences were detected between control animals and those treated with DOC/salt.

The gene for PDGF A chain also was transcriptionally active in aortic tissue (Fig. $2 \mathrm{~B}$ ). Three mRNAs of different sizes were present $(\sim 2.8,2.3$, and $1.7 \mathrm{~kb}$, respectively), with the 1.7-kb message being the most abundant. As with the B chain gene, the expression of the A chain gene was not altered after DOC/salt hypertension when compared with uninephrectomized rats or animals given DOC and a low salt diet. In experiments not shown, it was established that removal of the endothelium before RNA extraction did not alter the relative abundance of either the PDGF A- or B chain mRNA, again suggesting that the medial SMC is the predominant cell type responsible for the mRNA detected.

Representative data on the expression of IGF-I and -II are shown in Fig. 3. Aortic tissue expresses transcripts for IGF-I of at least two different sizes, $\sim 7.8$ and $0.8 \mathrm{~kb}$, respectively. The 

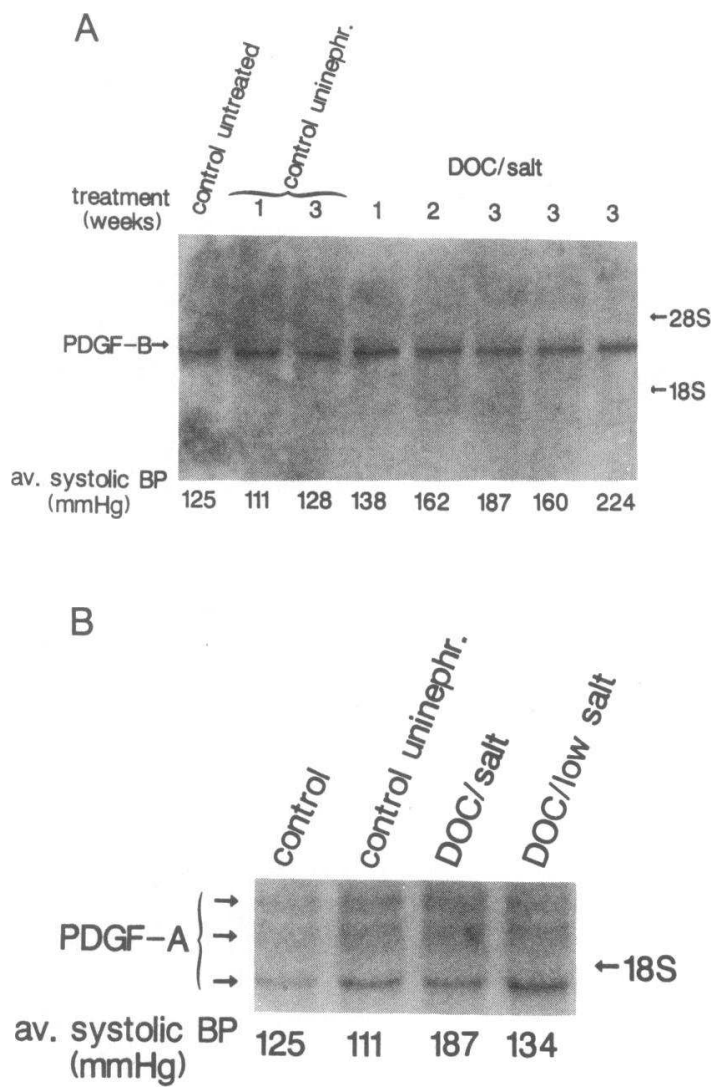

Figure 2. PDGF gene expression in aortic tissue. Northern blot hybridization analysis of rat aortic RNA from hypertensive and normotensive animals. Data are presented as in Fig. 1. (A) PDGF B chain gene expression. Weeks of treatment were as indicated above each lane. Control untreated and uninephrectomized animals were age matched. $1 \mathrm{~d}$ exposure time. (B) PDGF A chain gene expression. $2 \mathrm{~d}$ exposure time.

intensity of the 7.8-kb band underlines the relative abundance of this mRNA species as well as the quality of high mol wt RNA, which appeared undegraded. The mRNAs levels of IGF-I did not change with DOC/salt treatment or when DOC was administered with a low salt diet.
The expression of IGF-II in rat aorta is shown in Fig. $3 B$. Transcripts specific for IGF-II had a size of $\sim 3.9 \mathrm{~kb}$ and were readily detectable in $20 \mu \mathrm{g}$ of total RNA. No consistent change in relative abundance was seen between normal and uninephrectomized rats given DOC and low salt diet or made hypertensive by DOC/salt treatment.

Fig. $4 \mathrm{~A}$ shows the expression in aorta of ECGF, a precursor of acidic fibroblast growth factor (aFGF). A single mRNA species was identified with a size of $\sim 4.4 \mathrm{~kb}$. The level of ECGF mRNA did not change in response to DOC/salt hypertension.

Fig. $4 B$ shows the expression of bFGF in aorta. A single transcript of $\sim 7.0 \mathrm{~kb}$ was detected in aorta, but as for most of the growth factors that we found expressed in aorta, DOC/salt hypertension did not change the mRNA level of bFGF in comparison with control groups. The signal for bFGF was of lesser intensity than that for ECGF or any of the other growth factors tested. However, since human probes were used for these studies in the rat, it cannot be determined with certainty that the signals measured are an accurate reflection of the transcript's abundance.

\section{Discussion}

In the present study we have used seven human CDNA probes complementary to regions of PDGF B chain, PDGF A chain, IGF-I, IGF-II, ECGF, bFGF, and TGF- $\beta$ mRNA to identify the corresponding mRNA moieties in rat aortic tissue. An important finding was that mRNA for all the growth factors tested was present in aortic tissue, thereby establishing that growth factors, previously suggested to be involved in regulation of vascular growth based on studies with cultured cells, actually are made in aortic tissue. A second important observation made in this study was that aortic TGF- $\beta$ expression increased several-fold in DOC/salt hypertension, in contrast to the apparently constitutive expression of the other growth factors tested. The presence of TGF- $\beta$ in aortic tissue has not been shown previously and the increased expression during DOC/ salt hypertension represents a unique example of growth factor expression being altered in vascular tissue of hypertensive animals.

TGF- $\beta$ is a multifunctional modulator of cell metabolism and growth in vitro $(12,13)$ and affects both cultured endothe-
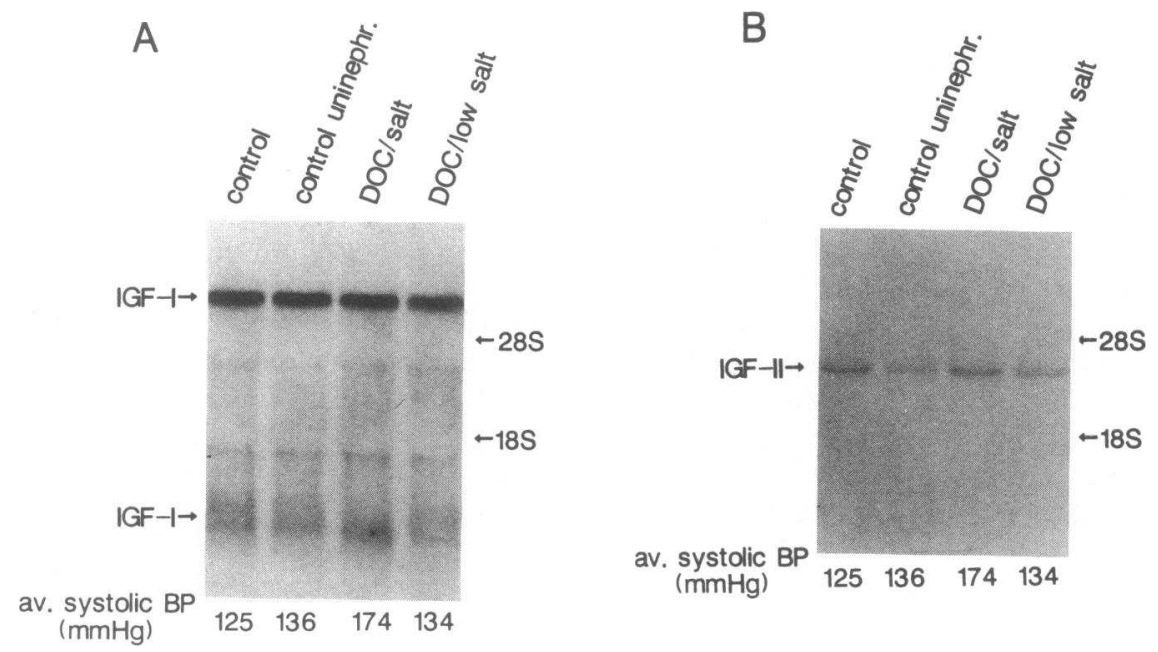

Figure 3. IGF expression in aortic tissue. Northern blot hybridization analysis of rat aortic RNA from hypertensive and normotensive animals. Data are presented as in Fig. 1 $(A)$ IGF-I gene expression. $16 \mathrm{~h}$ exposure time. (B) IGF-II gene expression. $3 \mathrm{~d}$ exposure time. 

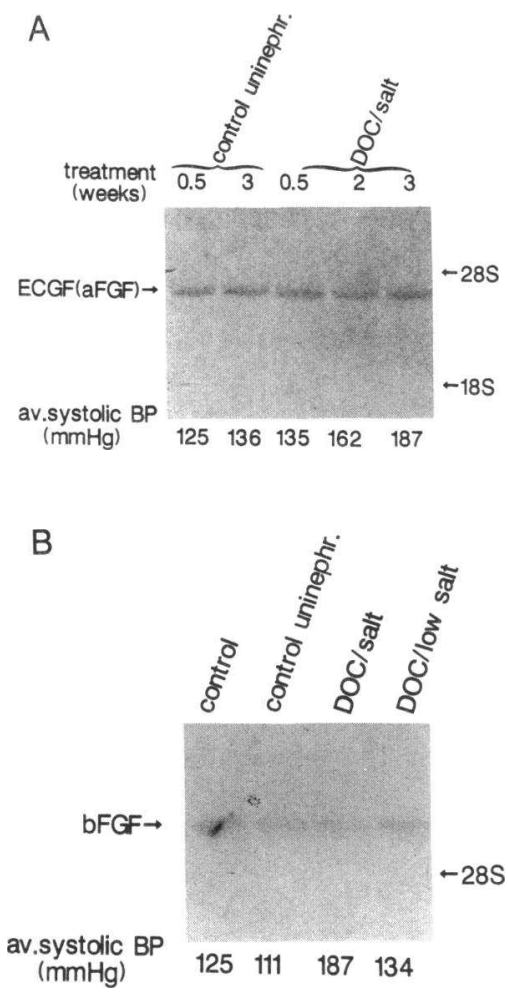

Figure 4. FGF expression in aortic tissue. Northern blot hybridization analysis of rat aortic RNA from normotensive and hypertensive animals. Data are presented as in Fig. 1. (A) ECGF (aFGF) gene expression. $3 \mathrm{~d}$ exposure time. (B) bFGF gene expression. $4 \mathrm{~d}$ exposure time.

lial cells and SMC by either inhibiting or modulating growth patterns $(13,25)$. In cultured SMC, TGF- $\beta$ may stimulate synthesis and secretion of proteoglycans and other components of the extracellular matrix $(13,26)$. Several of the effects produced by TGF- $\beta$ in various cultured cell systems also occur in aortic tissue during different forms of hypertension, including DOC/salt treatment $(3,5,6)$. The current study has focused only on the DOC/salt model of experimental hypertension; therefore, we cannot generalize to other models. Furthermore, we have measured the mRNA steady-state levels and did not determine whether the increased message level actually was associated with augmented expression of the protein, although a similar increase of TGF- $\beta$ mRNA in cell culture was associated with a parallel increase in TGF- $\beta$ protein (27). If increased TGF- $\beta$ synthesis and secretion accompany the increased expression of this gene in aortic tissue, this may be an important factor in the modulation of cell growth, phenotypic expression, and extracellular matrix accumulation in the aorta of $\mathrm{DOC} /$ salt hypertensive rats.

The presence of both PDGF A- and B chains in aortic tissue and the absence of appreciable change in mRNA expression after hypertension confirms a recent report showing similar but relatively low amounts of PDGF transcripts in aortic tissue of both newborn and adult rats (10). The PDGF B chain transcripts found in adult aortic tissue could arise from endothelial cells, residual adventitial cells, or blood cells, but it seems more likely that medial SMC are the synthetic site for aortic PDGF B chain in vivo. Our observation that the relative amount of the PDGF B chain mRNA was similar in aortas that either contained or did not contain endothelial cells indicates that endothelial cells are not the major source of this mRNA.

Our finding of IGF-I and IGF-II expression is the first evidence for the active transcription of the IGF genes in aorta

of adult animals, suggesting a role for IGFs in vivo as substances modulating endothelial and SMC function and growth. It seems that most of the proliferative action of PDGF on SMC in vitro is not direct but depends upon the synthesis, secretion, and autocrine activity of IGFs (7). A recent report has shown increased expression of IGF-I and IGF-II in benign and malignant smooth muscle tumors, suggesting an in vivo autocrine action on smooth muscle cells of different origin (28).

We also found both ECGF and bFGF expression in rat aorta. In cell culture, ECGF has been found in SMC, though not in endothelial cells (11). Recent reports indicate that bFGF can be produced by both vascular cell types in culture $(9,29)$, and we have found that bFGF is expressed also in endothelium-scraped aortic tissue (data not shown), consistent with the reported capacity of SMC in vitro to express bFGF. ECGF and bFGF are growth factors for cultured endothelial cells and SMC, bind to the same receptor, and are angiogenic in vivo (9). PDGF, IGF-I, and bFGF can interact on cultured rat SMC through their specific receptors (30), a phenomenon termed transmodulation, or receptor cross-talk (12). In vivo, interactions between PDGF and IGF-I appear to be important in stimulating fibroblast proliferation and wound repair (31). Thus, the physiological significance of multiple growth factor expression in aortic tissue may be to regulate cell growth and function through autocrine and paracrine mechanisms, supporting concepts developed through studies with cultured cells.

The effects of hypertension on gene expression in the cardiovascular system are just beginning to be studied. We have recently shown that the mRNA for a specific fatty acid binding protein was markedly suppressed in aortic tissue in three different models of experimental hypertension (32), and that hypertension induced isoform-specific modulation of $\mathrm{Na}^{+}, \mathrm{K}^{+}$ATPase subunits expressed in both cardiac and aortic tissue (33). The present report extends such studies on vascular gene expression to growth factors, and is consistent with a role for such substances in regulating the cellular changes that occur in vascular tissue in response to hypertension. Alterations in autocrine and paracrine regulation due to changes in growth factor expression may influence the development of vascular disease in large arteries or in resistance vessels.

\section{Acknowledgments}

We thank C.-H. Heldin, C. Betsholtz, P. Rotwein, M. Jansen, J. A. Abraham, J. C. Fiddes, D. Gospodarowicz, R. Derynck, and S. R. Farmer for their cDNA probes. Cynthia J. Nickerson, Robin $\mathbf{M}$. Drago, and Elizabeth Eastman provided invaluable technical assistance.

This work was supported by National Institutes of Health grant HL-18318 (hypertension National Research Development Center). R. Sarzani was partially supported by a grant from Dottorato di Ricerca in Scienze Endocrinologiche e Metaboliche, University of Modena, Modena, Italy.

\section{References}

1. Kannel, W. B., and P. Sorlie. 1975. Hypertension in Framingham. In Epidemiology and Control of Hypertension. O. Paul, editor. Stratton Intercontinental Medical Books, New York. 553-592.

2. Glagov, S. 1972. Hemodynamic risk factors: mechanical stress, mural architecture, medial nutrition, and the vulnerability of arteries to atherosclerosis. In The Pathogenesis of Atherosclerosis. R. W. 
Wissler and J. C. Geer, editors. Williams \& Wilkins Co., Baltimore. 164-199.

3. Chobanian, A. V. 1983. The influence of hypertension and other hemodynamic factors in atherogenesis. Prog. Cardiovasc. Dis. 26:177-196.

4. McGill, H. C., K. D. Carey, C. A. McMahan, Y. N. Marinez, T. E. Cooper, G. E. Mott, and C. J. Schwartz. 1985. Effects of two forms of hypertension on atherosclerosis in the hyperlipidemic baboon. Arteriosclerosis. 5:481-493.

5. Haudenshild, C. C., M. F. Prescott, and A. V. Chobanian. 1980. Effects of hypertension and its reversal on aortic intima lesions of the rat. Hypertension. 2:33-44.

6. Lichtenstein, A. H., P. Brecher, and A. V. Chobanian. 1986. Effects of deoxycorticosterone-salt hypertension on cell ploidy in the rat aorta. Hypertension. 8 (Suppl II):II-50-II-54.

7. Ross, R. E., W. Raines, and D. F. Bowen-Pope. 1986. The biology of platelet-derived growth factor. Cell. 46:155-169.

8. Sitaras, N. M., E. Sariban, P. Pantazis, B. Zetter, and H. N. Antoniades. 1987. Human iliac artery endothelial cells express both genes encoding the chains of platelet-derived growth factor (PDGF) and synthesize PDGF-like mitogen. J. Cell Physiol. 132:376-380.

9. Gospodarowicz, D., N. Ferrara, L. Schweigerer, and G. Neufeld. 1987. Structural characterization and biological functions of fibroblast growth factor. Endocr. Rev. 8:95-114.

10. Majesky, M. W., E. P. Benditt, and S. M. Schwartz. 1988. Expression and developmental control of platelet-derived growth factor A-chain and B-chain/Sis genes in rat aortic smooth muscle cells. Proc. Natl. Acad. Sci. USA. 85:1524-1528.

11. Winkles, J. A., R. Friesel, W. H. Burgess, R. Howk, T. Mehlman, R. Weinstein, and T. Maciag. 1987. Human vascular smooth muscle cells both express and respond to heparin-binding growth factor I (endothelial cell growth factor). Proc. Natl. Acad. Sci. USA. 84:7124-7128.

12. Sporn, M. B., and A. B. Roberts. 1988. Peptide growth factors are multifunctional. Nature (Lond.). 322:217-219.

13. Sporn, M. B., A. B. Roberts, L. M. Wakefield, and B. de Crombrugghe. 1987. Some recent advances in the chemistry and biology of transforming growth factor-beta. J. Cell Biol. 105:1039-1045.

14. Barrett, T. B., and E. P. Benditt. 1987. Sis (platelet-derived growth factor B chain) gene transcript levels are elevated in human atherosclerotic lesions compared to normal artery. Proc. Natl. Acad. Sci. USA. 84:1099-1103.

15. Chirgwin, J. M., A. E. Przybyla, R. J. MacDonald, and W. J. Rutter. 1979. Isolation of biologically active ribonucleic acid from sources enriched in ribonuclease. Biochemistry. 18:5294-5299.

16. Church, G. M., and W. Gilbert. 1984. Genomic sequencing. Proc. Natl. Acad. Sci. USA. 81:1991-1995.

17. Feinberg, A. P., and B. Vogelstein. 1984. A technique for radiolabeling DNA restriction endonuclease fragments to high specific activity. Anal. Biochem. 137:266-267.

18. Betsholtz, C., A. Johnsson, C.-H. Heldin, B. Westermark, P. Lind, M. S. Urdea, E. Eddy, T. B. Shows, K. Philpott, A. L. Mellor, T. J. Knott, and J. Scott. 1986. cDNA sequence and chromosomal localization of human platelet-derived growth factor A-chain and its expression in tumour cell lines. Nature (Lond.). 320:695-699.

19. Rotwein, P. 1986. Two insulin-like growth factor I messenger RNAs are expressed in human liver. Proc. Natl. Acad. Sci. USA. 83:77-81.
20. Jansen, M., F. M. A. van Schaik, H. van Tol, J. L. Van den Brande, and J. S. Sussenbach. 1985. Nucleotide sequences of cDNAs encoding precursors of human insulin-like growth factor II (IGF-II) and an IGF-II variant. FEBS (Fed. Eur. Biochem. Soc.) Lett. 179:243-246.

21. Jaye, M., R. Howk, W. Burgess, G. A. Ricca, I.-M. Chiu, M. W. Ravera, S. J. O'Brien, W. S. Modi, T. Maciag, and W. N. Drohan. 1986. Human endothelial cell growth factor: cloning, nucleotide sequence, and chromosome localization. Science (Wash. DC). 233:541545.

22. Abraham, J. A., A. Mergia, J. L. Whang, A. Tumolo, J. Friedman, K. A. Hjerrild, D. Gospodarowicz, and J. C. Fiddes. 1986. Nucleic sequence of a bovine clone encoding the angiogenic protein, basic fibroblast growth factor. Science (Wash. DC). 233:545-548.

23. Derynck, R., J. A. Jarret, E. Y. Chen, D. H. Eaton, J. R. Bell, R. K. Assoian, A. B. Roberts, M. B. Sporn, and D. V. Goeddel. 1985. Human transforming growth factor- $\beta$ complementary DNA sequence and expression in normal and transformed cells. Nature (Lond.). 316:701-705

24. Bond, J. F., and S. R. Farmer. 1983. Regulation of tubulin and actin mRNA production in rat brain: expression of a new $\beta$-tubulin mRNA with development. Mol. Cell. Biol. 3:1333-1342.

25. Majack, R. A. 1987. Beta-type transforming growth factor specifies organizational behavior in vascular smooth muscle cell cultures. J. Cell Biol. 105:465-471.

26. Chen, J.-K., H. Hoshi, and W. L. McKeehan. 1987. Transforming growth factor type $\beta$ specifically stimulates synthesis of proteoglycan in human adult arterial smooth muscle cells. Proc. Natl. Acad. Sci. USA. 84:5287-5291.

27. Van Obberghen-Schilling, E., N. S. Roche, K. C. Flanders, M. B. Sporn, and A. B. Roberts. 1988. Transforming growth factor $\beta 1$ positively regulates its own expression in normal and transformed cells. J. Biol. Chem. 263:7741-7746.

28. Hoppener, J. W. M., S. Mosselman, P. J. M. Roholl, C. Lambrechts, R. J. C. Slebos, P. de Pagter-Holthuizen, C. J. M. Lips, H. S. Jansz, and J. S. Sussenbach. 1988. Expression of insulin-like growth factor-I and -II genes in human smooth muscle tumours. EMBO (Eur. Mol. Biol. Organ.) J. 7:1379-1385.

29. Gospodarowicz, D., N. Ferrara, T. Haaparanta, and G. Neufeld. 1988. Basic fibroblast growth factor: expression in cultured bovine vascular smooth muscle cells. Eur. J. Cell Biol. 46:144-151.

30. Pfeifle, B., H. Boeder, and H. Ditschuneit. 1987. Interaction of receptors for insulin-like growth factor I, platelet-derived growth factor, and fibroblast growth factor in rat aortic cells. Endocrinology. 120:2251-2258.

31. Lynch, S. E., J. C. Nixon, R. B. Colvin, and H. N. Antoniades. 1987. Role of platelet-derived growth factor in wound healing: synergistic effects with other growth factors. Proc. Natl. Acad. Sci. USA. 84:7696-7700.

32. Sarzani, R., K. P. Claffey, A. V. Chobanian, and P. Brecher. 1988. Hypertension induces tissue-specific gene suppression of a fatty acid binding protein in rat aorta. Proc. Natl. Acad. Sci. USA. 85:7777-7781.

33. Herrera, V. L. M., A. V. Chobanian, and N. Ruiz-Opazo. 1988. Isoform-specific modulation of $\mathrm{Na}^{+}, \mathrm{K}^{+}$-ATPase alpha-subunit gene expression in hypertension. Science (Wash. DC). 241:221-223. 